Studia nad Autorytaryzmem i Totalitaryzmem 43, nr 3 Wrocław 2021

https://doi.org/10.19195/2300-7249.43.3.8

\author{
PIOTR MACHNIKOWSKI \\ ORCID: 0000-0002-9145-1311 \\ Uniwersytet Wrocławski \\ piotr.machnikowski@uwr.edu.pl
}

\title{
Badania nad totalitaryzmem — prawda historyczna i wolność indywidualna - prawo prywatne w służbie publicznej. Uwagi na tle „cywilnoprawnych” przepisów ustawy o IPN
}

Słowa kluczowe: badania nad totalitaryzmem, dobre imię państwa i narodu, wolność badań naukowych, prawo prywatne.

\author{
RESEARCH ON TOTALITARIANISM - THE HISTORICAL TRUTH \\ AND INDIVIDUAL FREEDOM - PRIVATE LAW IN PUBLIC SERVICE: \\ SOME REMARKS ON THE "CIVIL LAW" PROVISIONS OF THE IPN ACT
}

\begin{abstract}
The much-publicised and rather unfortunate amendment of 2018 to the Act on the Institute of National Remembrance introduced not only the controversial and subsequently repealed penal provisions, but also the provisions on "Protection of the good name of the Republic of Poland and the Polish Nation". According to these, protecting the good name of the Republic of Poland and the Polish Nation is subject to the provisions of the Civil Code. The intention of the lawmakers was to prevent the dissemination in public discourse of the false expression "Polish death camps" and similar expressions sometimes used to refer to Nazi German extermination camps located in the occupied territory of Poland.

The provision mandating the application of the provisions of the Civil Code on personal rights to the protection of the state and nation's good name may serve the intended purpose. However, its application may also be much broader, due to the vagueness of the wording used ("good name of the state and nation") and the powerful protection afforded to personal rights in the Civil Code.
\end{abstract}


The author discusses which provisions of the Civil Code can and which cannot be applied in this case. He also draws attention to the inadequacy of private law tools to protect public interests. $\mathrm{He}$ calls for a restrictive interpretation of the provision and recognizing a wide range of circumstances excluding the unlawfulness of an infringement in order to protect constitutional values such as freedom of expression, artistic creation, or scientific research.

Keywords: research on totalitarianism, good name of the state and the nation, freedom of scientific research, private law.

\section{Wprowadzenie}

Nowelizacja ustawy o Instytucie Pamięci Narodowej ${ }^{1}$ dokonana w styczniu 2018 roku $^{2}$ wprowadziła do niej nie tylko kontrowersyjne i uchylone następnie ${ }^{3}$ przepisy karne, ale także rozdział 6c zatytułowany „Ochrona dobrego imienia Rzeczypospolitej Polskiej i Narodu Polskiego”. Przedmiotem niniejszych uwag jest zawarty w nim art. 53o, który nakazuje stosować odpowiednio przepisy kodeksu cywilnego o ochronie dóbr osobistych do ochrony dobrego imienia Rzeczypospolitej Polskiej i Narodu Polskiego z tym zastrzeżeniem, że odszkodowanie lub zadośćuczynienie ma przysługiwać Skarbowi Państwa.

Interpretacja przepisów art. 53o ustawy o IPN nie jest zadaniem łatwym, zwłaszcza dla prawnika zajmującego się prawem prywatnym ${ }^{4}$. Wątpliwe mogą bowiem być już kwestie zasadnicze (i to one są przedmiotem tego opracowania): jaka konstrukcja prawna została tu zastosowana? Co jest w istocie przedmiotem ochrony i jakie są jej przesłanki? Pytania te przeplatają się z trzecim zagadnieniem, zasygnalizowanym obecnością cudzysłowu w tytule tego artykułu — czy rzeczywiście mamy do czynienia z instytucją prawa prywatnego (cywilnego)?

${ }^{1}$ Ustawa z dnia 18 grudnia 1998 r. o Instytucie Pamięci Narodowej - Komisji Ścigania Zbrodni przeciwko Narodowi Polskiemu, tekst jedn. Dz.U. z 2021 r. poz. 177 (dalej: ustawa o IPN).

2 Ustawą z dnia 26 stycznia 2018 r. o zmianie ustawy o Instytucie Pamięci Narodowej Komisji Ścigania Zbrodni przeciwko Narodowi Polskiemu, ustawy o grobach i cmentarzach wojennych, ustawy o muzeach oraz ustawy o odpowiedzialności podmiotów zbiorowych za czyny zabronione pod groźbą kary, Dz.U. z 2018 r. poz. 369.

3 Ustawą z dnia 27 czerwca 2018 r. o zmianie ustawy o Instytucie Pamięci Narodowej — Komisji Ścigania Zbrodni przeciwko Narodowi Polskiemu oraz ustawy o odpowiedzialności podmiotów zbiorowych za czyny zabronione pod groźbą kary, Dz.U. z 2018 r. poz. 1277.

${ }^{4}$ W literaturze poczyniono już wiele wnikliwych spostrzeżeń na tle tej regulacji, zob. zwłaszcza A. Pyrzyńska, Cywilnoprawna ochrona dobrego imienia Rzeczypospolitej Polskiej i Narodu Polskiego w świetle ustawy o Instytucie Pamięci Narodowej, „Zeszyty Prawnicze Biura Analiz Sejmowych Kancelarii Sejmu" 2019, nr 4, s. 23 n.; oraz B. Lackoroński, [w:] komentarz do art. 53 o ustawy o IPN, red. K. Osajda, Legalis. 


\section{Cel regulacji a jej zakres}

Przyczynę i cel wprowadzenia tej regulacji wyjaśnia uzasadnienie nowelizacji ze stycznia $2018 \mathrm{roku}^{5}$. Stwierdza się w nim mianowicie, że — w pewnym uproszczeniu — w obiegu publicznym występują takie określenia jak ,polskie obozy śmierci”, „polskie obozy zagłady” czy „polskie obozy koncentracyjne”, które są sprzeczne z prawdą historyczną i godzą w dobre imię Rzeczypospolitej Polskiej i Narodu Polskiego. Ponieważ dostępne środki przeciwdziałania temu zjawisku nie są wystarczająco efektywne, konieczne jest — oddając głos projektodawcy - „stworzenie skutecznych narzędzi prawnych pozwalających prowadzić wytrwałą i konsekwentną politykę historyczną polskich władz w zakresie przeciwdziałania fałszowaniu polskiej historii i ochrony dobrego imienia Rzeczypospolitej Polskiej i Narodu Polskiego". Tymi narzędziami miały być, głośno dyskutowane i w wyniku tej dyskusji uchylone, przepisy karne (art. 55a i art. 55b) oraz ,przepisy określające zasady dochodzenia roszczeń powstałych wskutek naruszenia dobrego imienia Rzeczypospolitej Polskiej i Narodu Polskiego". Wyjaśniając zamierzone znaczenie art. 53o ustawy o IPN, autor uzasadnienia projektu stwierdza, że „Naród Polski” to - zgodnie z preambułą Konstytucji Rzeczypospolitej Polskiej — wszyscy obywatele Rzeczypospolitej, a „Rzeczpospolita Polska" to nazwa państwa polskiego stanowiącego wedle art. 1 Konstytucji Rzeczypospolitej Polskiej dobro wszystkich obywateli. Zatem, ,według projektowanych uregulowań Rzeczpospolita Polska i Naród Polski mają dobra osobiste analogiczne jak osoby prawne".

Po lekturze uzasadnienia projektu trudno nie dostrzec rozbieżności między deklarowanym celem regulacji a jej rzeczywistą treścią. Zamierzeniem twórców ustawy - jak wynika z uzasadnienia — było przeciwstawienie się dość ściśle określonemu zjawisku polegającemu na przypisywaniu Polsce bądź Polakom odpowiedzialności za utworzenie i funkcjonowanie nazistowskich obozów koncentracyjnych i obozów zagłady. Zamierzenie zasługuje na uznanie, skuteczność przyjętej metody jego realizacji będzie mogła być oceniona dopiero w przyszłości. Tym natomiast, co budzi wątpliwości, jest szeroki i nieostro wyznaczony zakres zdarzeń, z którymi łączyć ma się odpowiedzialność. Nie sprowadza się on bowiem tylko do czynów odnotowanych w uzasadnieniu projektu, ale został zdefiniowany z użyciem pojęć „dobrego imienia Rzeczypospolitej Polskiej” i „dobrego imienia Narodu Polskiego”. Można założyć, że wygłaszanie twierdzeń o „polskich obozach zagłady” mieści się w zakresie zdarzeń rodzących

5 Rządowy projekt ustawy o zmianie ustawy o Instytucie Pamięci Narodowej - Komisji Ścigania Zbrodni przeciwko Narodowi Polskiemu, ustawy o grobach i cmentarzach wojennych, ustawy o muzeach, ustawy o odpowiedzialności podmiotów zbiorowych za czyny zabronione pod groźbą kary oraz ustawy o zakazie propagowania komunizmu lub innego ustroju totalitarnego przez nazwy budowli, obiektów i urządzeń użyteczności publicznej, druk nr 806 Sejmu VIII kadencji. 
odpowiedzialność, trudno jednak na podstawie samego brzmienia przepisu przyjąć, że zakres ten wyczerpuje. Paradoksalnie, wyznaczenie zakresu zastosowania ochrony przyznanej przez art. 53o ustawy o IPN mogło być łatwiejsze, dopóki obowiązywał art. 55a tej ustawy, który swój zakres zastosowania określał znacznie bardziej (choć wciąż nie dość) precyzyjnie. Stanowił on element kontekstu prawnego, który mógł być pomocny w zrozumieniu art. 53o ustawy o IPN. Dziś jednak kontekst ten ma walor wyłącznie historyczny.

\section{Zakres odesłania do przepisów kodeksu cywilnego}

Omawiany przepis ustawy o IPN jest przepisem odsyłającym - nakazuje stosować do ochrony dobrego imienia Rzeczypospolitej Polskiej i Narodu Polskiego w sposób odpowiedni przepisy kodeksu cywilnego o ochronie dóbr osobistych. Przepisem, do jakiego kieruje to odesłanie, jest przede wszystkim art. 24 $\S 1$ k.c., w myśl którego

Ten, czyje dobro osobiste zostaje zagrożone cudzym działaniem, może żądać zaniechania tego działania, chyba że nie jest ono bezprawne. W razie dokonanego naruszenia może on także żądać, ażeby osoba, która dopuściła się naruszenia, dopełniła czynności potrzebnych do usunięcia jego skutków, w szczególności ażeby złożyła oświadczenie odpowiedniej treści i w odpowiedniej formie. Na zasadach przewidzianych w kodeksie może on również żądać zadośćuczynienia pieniężnego lub zapłaty odpowiedniej sumy pieniężnej na wskazany cel społeczny.

Odesłaniem z art. 53o ustawy o IPN objęty został więc także przepis, do którego odsyła art. $24 \S 1$ k.c. zd. 2 , to jest art. 448 k.c., dotyczący zadośćuczynienia pieniężnego ${ }^{6}$.

Kolejnym z przepisów potencjalnie objętych odesłaniem $\mathrm{z}$ art. 53o ustawy o IPN jest art. $24 \S 2$ k.c., zgodnie z którym „Jeżeli wskutek naruszenia dobra osobistego została wyrządzona szkoda majątkowa, poszkodowany może żądać jej naprawienia na zasadach ogólnych". Zastosowanie tego przepisu pozwalałoby stosować również dalsze przepisy kodeksu cywilnego dotyczące naprawienia szkody majątkowej. Wydaje się zresztą sprzyjać temu wnioskowi treść art. 53o zd. 3 ustawy o IPN, zgodnie z którym Skarbowi Państwa przysługuje nie tylko zadośćuczynienie, ale też odszkodowanie ${ }^{7}$. Wniosek ten byłby jednak przedwczesny. Odpowiedzialność odszkodowawcza może bowiem powstać wówczas, gdy naruszenie dobra osobistego powoduje szkodę majątkową u podmiotu, którego naruszenie to dotyka. By móc doznać szkody majątkowej, trzeba mieć zdolność prawną $\mathrm{w}$ rozumieniu prawa cywilnego, to ona pozwala bowiem być podmiotem praw majątkowych, w których sferze szkoda może zaistnieć. Jak zostanie dalej wyjaśnione, art. 53o ustawy o IPN ma na celu ochronę dóbr przysługujących

\footnotetext{
6 Zob. A. Pyrzyńska, op. cit., s. 36 n.

7 Zob. ibidem, s. 50 n.
} 
bytom niebędącym podmiotami prawa cywilnego, a więc niezdolnym do poniesienia szkody. Jeżeli to samo zachowanie, które naruszyłoby dobre imię Rzeczypospolitej Polskiej albo Narodu Polskiego, wyrządzi jednocześnie szkodę w czyimś mieniu, będzie ona podlegała naprawieniu na zasadach ogólnych, jednak nie będzie traktowana jako skutek naruszenia dobrego imienia państwa bądź narodu, bo naruszenia te dotykają dóbr przysługujących różnym podmiotom.

Jeszcze bardziej wątpliwe jest, czy można mówić o odpowiednim stosowaniu art. $24 \S 3$ k.c. $^{8}$ Tym razem problem dotyczy jednak tego, czy przepis ten należy do kategorii ,przepisów o ochronie dóbr osobistych”. Stanowi on bowiem, że „Przepisy powyższe [to jest art. $24 \S 1$ i 2 - przyp. aut.] nie uchybiają uprawnieniom przewidzianym $\mathrm{w}$ innych przepisach, w szczególności w prawie autorskim oraz w prawie wynalazczym". Nie przyznaje on zatem żadnych uprawnień ani nie nakłada żadnych obowiązków związanych z dobrami osobistymi, a jedynie rozstrzyga o wzajemnej relacji instytucji ochrony dóbr osobistych i innych środków ochrony dóbr i interesów, których zakres zastosowania mogłoby spełniać zdarzenie kwalifikowane jako zagrożenie czy naruszenie dobra osobistego. Innymi słowy zastosowanie na przykład przepisów o ochronie niemajątkowych praw autorskich nie jest prawnie powiązane $\mathrm{z}$ tym, czy doszło do zagrożenia czy naruszenia dobra osobistego w rozumieniu art. 23 i 24 k.c. Ani nie jest ono uwarunkowane takim zagrożeniem czy naruszeniem, ani też ingerencja $\mathrm{w}$ dobro osobiste nie pozwala powoływać się na prawnoautorskie środki ochrony, jeżeli nie zostały spełnione przesłanki ich zastosowania określone w prawie autorskim. Przepisy prawa autorskiego, prawa prasowego itp. nie są przepisami o ochronie dóbr osobistych i nie stają się nimi przez to, że art. $24 \S 3$ k.c. dopuszcza zbieg wynikających $z$ nich uprawnień z roszczeniami przewidzianymi w art. $24 \S 2$ i 3 k.c. Nie będą więc, moim zdaniem, miały zastosowania do ochrony dóbr chronionych przez art. 53o ustawy o IPN.

\section{Przedmiot ochrony}

Przepisy art. 53o i 53p ustawy o IPN nie pozostawiają wątpliwości, że tym, co ma być chronione dzięki odpowiedniemu stosowaniu przepisów kodeksu cywilnego, jest dobre imię Rzeczypospolitej Polskiej i dobre imię Narodu Polskiego. Dobre imię to pojęcie odnoszone w nauce i judykaturze z zakresu prawa cywilnego do osób prawnych i oznaczające dobrą opinię innych o osobie, szacunek, reputację czy renomę, jakimi cieszy się ona w otoczeniu ${ }^{9}$. Dobre imię jest więc pewną wartością (wysoko cenionym stanem rzeczy) odnoszącą się do podmiotu.

8 Pozytywnie odpowiada na to pytanie A. Pyrzyńska; ibidem, s. 36.

9 Zob. np. J. Frąckowiak, [w:] System Prawa Prywatnego, red. M. Safjan, t. 1, Warszawa 2012, s. 1196; M. Pazdan, [w:] ibidem, s. 1238. 
Jak trafnie wskazuje się w literaturze, zgodnie zresztą ze stanowiskiem projektodawcy, Rzeczpospolita Polska to państwo polskie, a zatem podmiot prawa publicznego i prawa międzynarodowego ${ }^{10}$. Tak określony byt nie jest jednak, co istotne, podmiotem prawa prywatnego, nie jest bowiem osobą fizyczną ani osobą prawną czy też inną organizacją wyposażoną przez ustawę w zdolność prawną ${ }^{11}$. Państwo jako organizacja polityczna społeczeństwa istnieje niezależnie od prawa prywatnego - to ono stanowi prawo, w tym prawo prywatne. Dopiero gdy w swoim działaniu państwo wchodzi w relacje z innymi podmiotami, oparte na zasadzie równorzędności i normowane prawem cywilnym, jest osobą prawną, którą ustawa nazywa Skarbem Państwa. Ustawa o IPN przestrzega tego rozróżnienia, przypisując dobre imię państwu, a uprawnienia związane $\mathrm{z}$ jego naruszeniem - Skarbowi Państwa.

Nieco trudniejsze jest ustalenie nosiciela drugiego z przedmiotów ochrony. Projektodawca odwołuje się tu do preambuły Konstytucji, w której „Naród Polski” oznacza „wszystkich obywateli Rzeczypospolitej”" ${ }^{2}$. Pojęcie narodu występuje także w art. 4 Konstytucji, w którym narodowi przyznana jest władza zwierzchnia w państwie. Ten przepis jest podstawą wniosku o podmiotowości narodu $^{13}$, jest to jednak nadal podmiotowość publiczno-, a nie prywatnoprawna.

Tym obu bytom - państwu i narodowi - przysługuje dobre imię, będące przedmiotem ochrony w art. 53o ustawy o IPN. Można zastanawiać się, czy w sytuacji istnienia państwa jako politycznej formy, w jakiej zorganizowany jest naród, potrzebne było rozróżnianie tych bytów i czy da się rozdzielić dobre imię państwa od dobrego imienia narodu, który to państwo stworzył i sprawuje w nim władzę. Nie ma to jednak zasadniczego znaczenia. Bardziej istotne jest to, że wartość ta związana jest z bytami, które nie stanowią podmiotów prawa prywatnego. Twierdzenie projektodawcy, że „według projektowanych uregulowań Rzeczpospolita Polska i Naród Polski mają dobra osobiste analogiczne jak osoby prawne" może być zaaprobowane jedynie, gdy nacisk położy się na słowo „analogiczne” — byty te nie mogą mieć dóbr osobistych w rozumieniu prawa prywatnego, bo nie są osobami w rozumieniu tego prawa. Natomiast ustawa stanowi, a raczej przyjmuje założenie, że z państwem i narodem wiążą się takie wartości, które gdy przysługują podmiotom prawa cywilnego, są ich dobrami osobistymi. Można mówić tu jedynie o założeniu ustawodawcy, a nie jego stanowieniu, ponieważ dobre imię jest czymś, co istnieje niezależnie od prawa. Nie da się zadekretować dobrego imienia ustawą, można nią tylko je chronić.

Warto zauważyć, że podobieństwo użytej w ustawie o IPN konstrukcji dobrego imienia do tak samo nazywanego dobra osobistego osoby prawnej jest dość powierzchowne. Inne wydaje się bowiem uzasadnienie istnienia obu dóbr, ich

10 Zob. A. Pyrzyńska, op. cit., s. 26; B. Lackoroński, op. cit., uw. 17.

11 Zob. A. Pyrzyńska, op. cit., s. 26.

12 Zob. B. Lackoroński, op. cit., uw. 18.

13 Zob. A. Pyrzyńska, op. cit., s. 26 i powołaną tam literaturę. 
źródło. Pojęcie dobra osobistego pierwotnie odnoszone było do osoby fizycznej i w odniesieniu do tej kategorii podmiotów dobra osobiste uważane są za przejawy godności osoby ludzkiej. Do osób prawnych, zgodnie z art. 43 k.c., przepisy o ochronie dóbr osobistych osób fizycznych stosuje się odpowiednio. Podobieństwo między dobrami osobistymi osób fizycznych i dobrami osobistymi osób prawnych dotyczy jednak raczej konstrukcji niż idei. Ustawodawca posłużył się modelem ochrony dóbr osobistych osób fizycznych, by na ten wzór zbudować podobną ochronę dla pewnych interesów niemajątkowych jednostek organizacyjnych. Ochrona ta nie opiera się jednak na tych samych założeniach aksjologicznych, bo jednostki organizacyjne nie są istotami żyjącymi i myślącymi, które miałyby godność przysługującą im z samego faktu istnienia. Osoby prawne są tworzone dla określonych celów, dla prowadzenia pewnej działalności - gospodarczej, publicznej czy innej. Prowadzenie tej działalności wymaga pewnych cech czy właściwości o charakterze niemajątkowym, takich jak, między innymi, dobre imię. Wydaje się jednak, przynajmniej intuicyjnie, że gdy myślimy o dobrym imieniu państwa czy, zwłaszcza, narodu, jego źródeł poszukujemy raczej w godności członków narodu i obywateli państwa niż w potrzebie zapewnienia sprawności jego działania ${ }^{14}$. Nie znaczy to jednak, że dobre imię Narodu Polskiego odpowiada co do istoty godności (czci) człowieka - nie jest tak, bo naród nie jest osobą mającą osobową godność, ale zbiorowością ludzi. Zbiorowość ta może — zależnie od przyjętego rozumienia narodu — obejmować tylko żywych albo też umarłych i może być wspólnotą określoną etnicznie, przez kulturę, przez terytorium bądź w inny jeszcze sposób. Jeżeli więc dobre imię państwa czy narodu ma być pojęciem w jakiś sposób pokrewnym dobrom osobistym człowieka, to chyba tylko jako reprezentacja pewnej wspólnej dla wszystkich członków tego narodu i w tym sensie zbiorowej godności (poczucia przynależności do wspólnoty i dumy z jej dawnych i obecnych dokonań) ${ }^{15}$.

\section{Mechanizm ochrony}

Przedstawione uwagi wydają się mieć konsekwencje dla rozumienia i stosowania skonstruowanego w ustawie mechanizmu ochrony dobrego imienia.

Dominująca obecnie cywilnoprawna koncepcja dóbr osobistych opiera się na założeniu o przysługiwaniu podmiotom prawa cywilnego pewnych indywidualnych dóbr (wartości), które są chronione prawami podmiotowymi bezwzględ-

14 Podobnie ibidem, s. 28.

15 W tym kierunku ibidem, tam o kolektywnej ochronie wszystkich obywateli państwa polskiego i odwołanie do art. 1 Konstytucji i występującego w nim pojęcia dobra wspólnego. O publicznym charakterze interesu chronionego omawianą regulacją pisze B. Lackoroński, op. cit., uw. 19. Podobnie R. Guzik, Komentarz do ustawy o Instytucie Pamięci Narodowej - w zakresie zmian wprowadzonych ustawami z dnia 26 stycznia 2018 r. oraz z dnia 27 czerwca 2018 r., LEX. 
nymi ${ }^{16}$. Ochrona ta polega zatem na przyjęciu, że istnieje pewna sfera wyłączności korzystania z określonych wartości ściśle związanych z podmiotem, tworzona czy chroniona przez prywatnoprawny nakaz nieingerowania $\mathrm{w}$ dobra osobiste. Zagrożenie bądź naruszenie tego obowiązku o charakterze powszechnym i negatywnym (zakazu) uzasadnia powstanie po stronie podmiotu, którego dobra osobiste naruszono, uprawnień skonkretyzowanych podmiotowo i przedmiotowo (roszczeń) — zakazowych lub restytucyjnych. Sam obowiązek jest jednak w miarę ściśle określony, odnosi się bowiem do takich dóbr, których nazwy ustawowe są wprawdzie zwykle nieostre, jednak ich istnienie jest utrwalone w świadomości społecznej, a rozumienie dość jednolite. W wypadku godności osoby fizycznej jest ona podstawową w naszej kulturze wartością moralną. Przyznanie jej ochrony prawnej $\mathrm{w}$ formie powszechnego zakazu jej naruszania (sankcjonowanego odpowiedzialnością z art. 24 k.c.) jest powtórzeniem istniejącego już, mocno ugruntowanego i powszechnie zrozumiałego nakazu moralnego. Nie sądzę, by to samo dało się powiedzieć o przedmiocie ochrony wskazanym w art. 53o ustawy o IPN. Dobre imię państwa i dobre imię narodu nie wydają się wartościami samoistnymi oraz powszechnie rozpoznawanymi i ściśle zdefiniowanymi w naszym społeczeństwie. By się o tym przekonać, wystarczy przeprowadzić prosty eksperyment myślowy, podstawiając w miejsce Rzeczypospolitej Polskiej i Narodu Polskiego jakiekolwiek inne państwo czy naród i zadając sobie pytanie, do jakich powinności poczuwamy się względem dobrego imienia tego państwa czy narodu. Prawdopodobnie do nielicznych i słabych. Na pewno nieproporcjonalnie mniejszych od powinności względem naszego narodu i państwa. Fakt, że powinności takie odczuwamy jednak względem własnego państwa i narodu, pokazuje, że w sferze moralnej prawdopodobnie nie mamy do czynienia z nakazem ochrony dobrego imienia zbiorowości jako takiej, ale z nakazem szacunku wobec innych członków własnej wspólnoty, dawnych i obecnych. Jednak to nie taki nakaz jest przedmiotem sankcji w ustawie o IPN, skoro odnosi się ona także (a w zamyśle autorów przepisu chyba wręcz przede wszystkim) do osób spoza tej wspólnoty. Prowadzi to do wniosku, że przez wprowadzenie do systemu prawnego art. 53o ustawy o IPN nie tylko ustanowiono normę zakazującą naruszania pewnej uznanej w społeczeństwie wartości, lecz także, przynajmniej w jakimś stopniu, wykreowano tę wartość.

W takich przypadkach szczególnie istotne jest, by treść formułowanego nakazu była jednoznaczna. W wypadku art. 53o ustawy o IPN treść nakazu jednoznaczna nie jest, co może być kłopotliwe dla jego adresatów, czyli dla nas wszystkich. Trudno bowiem stwierdzić z pewnością, jakie wypowiedzi mogą zostać uznane za godzące $\mathrm{w}$ dobre imię państwa albo narodu. Wątpliwe może być zarówno to, jaki musiałby być przedmiot zniesławiającego twierdzenia, by można było uznać je za wymierzone w państwo bądź naród (czy samo użycie

${ }^{16}$ Poglądy w tej kwestii referuje M. Pazdan, op. cit., s. 1268 n. 
słowa „Polska” albo „Polacy” powoduje już, że wypowiedź odnosi się do Rzeczypospolitej Polskiej bądź Narodu Polskiego, czy też konieczne jest jakieś dookreślenie?), jak i to, jaka treść wypowiedzi może godzić w dobre imię tych bytów. Należy bezwzględnie zgodzić się z poglądem, że wypowiedź prawdziwa nie może być zniesławiająca ${ }^{17}$. Równie bezsporne powinno być, że postawienie zarzutu oczywiście sprzecznego z niewątpliwie ustaloną prawdą historyczną narusza dobre imię. To, co mieści się między tymi przypadkami, pozostaje jednak niejasne. A nie jest to sprawa błaha, skoro przyznanie Skarbowi Państwa roszczeń w związku z naruszeniem dobrego imienia Rzeczypospolitej Polskiej lub Narodu Polskiego jest technicznoprawną formą nałożenia na każdego zakazu naruszania tych dóbr, a więc ograniczenia wolności.

$\mathrm{Na}$ tym tle co najmniej nieoczywista staje się kwalifikacja omawianej regulacji jako należącej do prawa prywatnego. Jak wiadomo, wyróżnianie w systemie prawa dziedziny nazywanej prawem prywatnym czy cywilnym nie opiera się na jednym i powszechnie aprobowanym kryterium ${ }^{18}$. Najbardziej rozpowszechniony obecnie pogląd przyjmuje, że tym, co rozstrzyga o zaliczeniu norm prawnych do podsystemu prawa prywatnego, jest zastosowana przez prawodawcę metoda regulacji, rozumiana jako koncepcja czy sposób kształtowania relacji między podmiotami prawa. Cechą prawa prywatnego jest przyznanie podmiotom prawa autonomii woli oraz oparcie relacji między podmiotami (stosunków cywilnoprawnych) na zasadzie równorzędności pozycji. Mówiąc o autonomii woli jako fundamencie prawa prywatnego, ma się zatem na myśli nie tylko to, że istnieją w nim podmioty mające swoje własne interesy, ale przede wszystkim to, że interesów tych chronią one własnymi decyzjami, którym prawo w oznaczonym przez siebie zakresie przyznaje skuteczność. Równorzędność podmiotów polega na tym, że ci, do których skierowana jest regulacja cywilnoprawna, co do zasady mają wobec siebie równą pozycję prawną — ich zakres kompetencji czy możliwości działania jest formalnie taki sam, możliwości ich wpływania na sferę praw i obowiązków innego podmiotu poddane są takim samym regułom i ograniczeniom. Ta, z grubsza tylko zarysowana, charakterystyka prawa prywatnego pozwala zrozumieć, dlaczego nazwanie regulacji art. 53o ustawy o IPN „cywilnoprawną” wymaga użycia cudzysłowu. Jest ona prywatnoprawna w czysto technicznym znaczeniu tego słowa - przyznaje podmiotowi prawa prywatnego (Skarbowi Państwa) pewne uprawnienia wobec innego podmiotu prawa prywatnego. Nie jest jednak prywatnoprawna w głębszym i zasadniczym znaczeniu - nie chroni indywidualnego interesu autonomicznego i równorzędnego względem innych podmiotu. Dlatego o ile można mówić o stosunku cywilnoprawnym powstającym na skutek naruszenia dobrego imienia Rzeczypospolitej Polskiej czy Narodu Polskiego, to nie da się wskazać relacji normowanej prawem prywatnym, istniejącej przed

17 Zob. A. Pyrzyńska, op. cit., s. 38 n.; B. Lackoroński, op. cit., uw. 21.

18 Zob. np. M. Safjan, [w:] System Prawa Prywatnego, t. 1, s. 32 n. 
tym naruszeniem, a ramach której to relacji funkcjonowałby przedmiot ochrony - dobre imię. Jest to relacja między państwem bądź zbiorowością je tworzącą a jednostką; relacja publicznoprawna ${ }^{19}$. Ujawnia się to już w konstrukcji przyjętej w ustawie o IPN. Prawodawca wskazuje bowiem podmiot uprawniony do świadczeń pieniężnych z tytułu naruszenia dobrego imienia państwa czy narodu, nie wskazuje natomiast podmiotu uprawnionego do tego, co jest istotą konstrukcji ochrony dóbr osobistych w prawie cywilnym - żądania zaniechania naruszeńn ${ }^{20}$. Zaniechania naruszeń może żądać ten, czyje dobro jest chronione. Musi on jednak być podmiotem prawa prywatnego. Ustawa nie wskazuje takiego podmiotu, poprzestając na wyznaczeniu jego reprezentanta w procesie. Potwierdza to wniosek, że mamy do czynienia z publicznoprawnym obowiązkiem, nałożonym w interesie ogółu, a nie w interesie indywidualnym.

Wątpliwości co do przedmiotu ochrony i zakresu sformułowanego w ustawie zakazu mogą mieć znaczenie dla stosowania przepisów kodeksu cywilnego. Stosowanie to ma być odpowiednie, co pozwala na dokonywanie niezbędnych modyfikacji w celu dostosowania przepisów objętych odesłaniem do sytuacji, w której mają być stosowane.

Z nakazu odpowiedniego stosowania przepisów kodeksu cywilnego wynika, że do powstania roszczeń ochronnych nie dojdzie, gdy zagrożenie lub naruszenie dobra osobistego nie jest bezprawne. Nie jest ono bezprawne, gdy naruszyciel może powołać się na szczególną okoliczność czy uprawnienie usprawiedliwiające wkroczenie w cudze dobro osobiste. Wśród tych okoliczności - w przypadku naruszenia czci osoby fizycznej bądź dobrego imienia osoby prawnej - szczególne znaczenie praktyczne ma fakt, że naruszający to dobro działa w granicach przysługującej mu i prawnie chronionej wolności, takiej jak wolność prasy, swoboda wypowiedzi, swoboda twórczości, wolność pozyskiwania i przekazywania informacji, wolność działalności naukowej itp. Wówczas do rozstrzygnięcia o bezprawności naruszenia lub jej braku konieczne jest porównanie wagi obu kolidujących dóbr - naruszonego dobra osobistego i realizowanej przez naruszyciela wolności. Obszerna literatura i orzecznictwo dotyczące tego zagadnienia, zwłaszcza w kontekście działalności naukowej czy dziennikarskiej, są — oczywiście zasadnie - powoływane w dyskusji nad art. 53o ustawy o IPN czy też w podobnym kontekście ochrony dóbr osobistych związanych poczuciem tożsamości narodowej (których istnienie jest zresztą sporne) ${ }^{21}$.

19 Podobnie A. Pyrzyńska, op. cit., s. 25 n.

${ }^{20}$ A. Pyrzyńska (ibidem, s. 30 n.) za stronę stosunku cywilnoprawnego nawiązanego na skutek naruszenia art. 53o ustawy o IPN uznaje Skarb Państwa i, jak rozumiem, pojęciem naruszenia art. 53o obejmuje również stan zagrożenia dobrego imienia wymienionych w nim podmiotów. Wiąże się to z przyjęciem przez autorkę, że art. 53o jest źródłem zakazu zagrażania i naruszania dobrego imienia tych podmiotów. Sądzę jednak, że odsyłający charakter przepisu każe upatrywać źródła normy zakazującej w przepisie, do którego kieruje odesłanie, czyli w art. 24 k.c.

21 Zob. np. J. Sadomski, Konflikt zasad - ochrona dóbr osobistych a wolność prasy, Warszawa 2008; J. Balcarczyk, Prawo do dobrego imienia postaci historycznej a granice wolności wypowiedzi dotyczacej wydarzeń dziejowych, [w:] Prace z prawa cywilnego dla uczczenia pamięci 
Z wcześniejszych rozważań wynikają jednak dwa spostrzeżenia, które mogą - w ramach procedury odpowiedniego stosowania przepisów - uzasadniać korektę mechanizmów wypracowanych w toku stosowania przepisów o dobrach osobistych. Pierwsze dotyczy nieostrości nałożonego przez art. 53o ustawy o IPN obowiązku. Trudność w ustaleniu jego granic uzasadnia rozstrzyganie przypadków granicznych czy wątpliwych na korzyść potencjalnego naruszyciela. Drugie odnosi się do publicznego, a nie prywatnego charakteru dobra chronionego omawianym przepisem i jego co najwyżej luźnego związku z indywidualną godnością człowieka. O ile godność, której emanacją są cywilnoprawne dobra osobiste, niewątpliwie jest fundamentalną wartością konstytucyjną, wyrażoną zwłaszcza w preambule i w art. 30 Konstytucji, to dobre imię Rzeczypospolitej Polskiej i Narodu Polskiego takiego statusu nie ma. Konstytucja nadaje wysoki status dziedzictwu narodowemu, ono jednak obejmuje nie tylko to, co przysparza dumy, ale $\mathrm{i}$ to, co jest ważne jako źródło bolesnej nauki ${ }^{22}$. Te wartościowania prawodawcy konstytucyjnego też warto uwzględniać, rozstrzygając przypadki kolizji dóbr chronionych art. 53o ustawy o IPN z dobrami chronionymi konstytucyjnie, takimi jak wolność wypowiedzi, wolność twórczości artystycznej czy wolność badań naukowych.

\section{Podsumowanie}

Badanie i dokumentowanie losów i postaw Polaków wobec totalitaryzmów $\mathrm{XX}$ wieku jest ważnym zadaniem. Na zadanie to składa się na nią zarówno ochrona członków naszego narodu przed nieprawdziwymi i krzywdzącymi zarzutami, jak i zapewnienie swobody działania tym, którym obowiązek zawodowy i moralny nakazuje formułować i uzasadniać zarzuty rzetelnie zbadane i udokumentowane. Jedno i drugie służy dobru narodu i państwa — o wielkości i odwadze narodu świadczy chęć poznania prawdy o sobie, nawet gdy nie jest ona łatwa ani wygodna. Dlatego niezbędne jest, by omawiane w tym opracowaniu regulacje były używane powściągliwie i tylko w tym celu, dla którego je ustanowiono, nawet gdy ich szerokie sformułowanie wydaje się pozwalać na więcej. Powinny one przeciwdziałać szerzeniu niewątpliwej nieprawdy. Ich stosowanie, a tym bardziej samo obowiązywanie, nie może jednak zniechęcać do poszukiwania prawdy.

Profesora Jana Kosika, red. P. Machnikowski, („Prawo” 308), Wrocław 2009, s. 15 n.; L. Jurek, Swoboda wypowiedzi a ochrona dóbr osobistych na tle spraw zwiazanych z kultem pamięci osoby bliskiej, tożsamościa narodowa i prawdą historyczna, [w:] Prawda historyczna a odpowiedzialność prawna za jej negowanie lub znieksztatcanie, red. A. Radwan, M. Berent, Warszawa 2019, s. 223 n.; A. Pyrzyńska, op. cit., s. 41; B. Lackoroński, op. cit., uw. 20; F. Rakiewicz, Poczucie tożsamości narodowej jako dobro osobiste w świetle polskiego prawa cywilnego, „Studia Prawa Prywatnego” 2011, nr 2, 3; oraz 2012, nr 1.

22 Zob. M. Florczak-Wątor, [w:] Konstytucja RP. Komentarz, t. 1, red. M. Safjan, L. Bosek, Warszawa 2016, s. 288. 


\section{Bibliografia}

Balcarczyk J., Prawo do dobrego imienia postaci historycznej a granice wolności wypowiedzi dotyczacej wydarzeń dziejowych, [w:] Prace z prawa cywilnego dla uczczenia pamięci Profesora Jana Kosika, red. P. Machnikowski, („Prawo” 308), Wrocław 2009.

Guzik R., Komentarz do ustawy o Instytucie Pamięci Narodowej - w zakresie zmian wprowadzonych ustawami z dnia 26 stycznia 2018 r. oraz z dnia 27 czerwca 2018 r., LEX.

Jurek L., Swoboda wypowiedzi a ochrona dóbr osobistych na tle spraw zwiazanych z kultem pamięci osoby bliskiej, tożsamościa narodowa i prawda historyczna, [w:] Prawda historyczna a odpowiedzialność prawna za jej negowanie lub znieksztatcanie, red. A. Radwan, M. Berent, Warszawa 2019.

Konstytucja RP. Komentarz, red. M. Safjan, L. Bosek, Warszawa 2016.

Lackoroński B., [w:] Komentarz do art. 53o ustawy o IPN, red. K. Osajda, Legalis.

Pyrzyńska A., Cywilnoprawna ochrona dobrego imienia Rzeczypospolitej Polskiej i Narodu Polskiego w świetle ustawy o Instytucie Pamięci Narodowej, „Zeszyty Prawnicze Biura Analiz Sejmowych Kancelarii Sejmu" 2019, nr 4.

Rakiewicz F., Poczucie tożsamości narodowej jako dobro osobiste w świetle polskiego prawa cywilnego, „Studia Prawa Prywatnego” 2011, nr 2, 3; 2012, nr 1.

Sadomski J., Konflikt zasad - ochrona dóbr osobistych a wolność prasy, Warszawa 2008.

System Prawa Prywatnego, t. 1, red. M. Safjan, Warszawa 2012. 